\title{
ANALISIS KEPEMILIKAN MANAJERIAL DAN KINERJA KEUANGAN PERUSAHAAN SEBELUM DAN SETELAH MERGER
}

\author{
Deny Ismanto \\ Universitas Ahmad Dahlan \\ denoxis@yahoo.com
}

\begin{abstract}
The purpose of this research is to find any changes managerial and financial performance of the company before and after a merger. Managerial kepemilkan measured by the number of managerial compared with the number of shares outstanding. Measured by the number of managerial ownership managerial compared with the number of shares outstanding. Then to the company financial ratios are measured with a total assets and turnover net profit margin, and return on assets. The analysis was conducted using one sample t-test and paired sample test. Based on different paired test sample test May be known that the significance of tailed 0,286 ( 2 ) on the level of trust $95 \%$. Because probability significance ( 0,286) larger than 0.05 then can conclude that there is no difference between managerial possession before and after the merger. Based on test different t-test can be seen that the significance of the total turnover ( 0,085) assets, net profit margin (0,362), and return on assets (0,531) 95 percent in the level of trust. Greater significance because the probability of 0.05 it can be concluded that there is no difference between the company financial performance before and after a merger.
\end{abstract}

Keywords: mergers, ownership managerial and the company performance

\section{PENDAHULUAN}

Persaingan usaha diantara perusahaanperusahaan semakin meningkat. Kondisi demikian menuntut perusahaan untuk selalu mengembangkan strategi perusahaan supaya dapat mempertahankan eksistensinya. Salah satu strategi yang dapat dilakukan oleh perusahaan adalah melalui penggabungan usaha. Penggabungan usaha adalah penyatuan dua atau lebih perusahaan yang terpisah menjadi satu entity ekonomi karena satu perusahaan menyatu dengan perusahaan lain atau memperoleh kendali atas aktiva dan operasi perusahaan lain.

Menurut Wahidahwati (2002:1088) untuk mengurangi agency cost dapat dilakukan dengan meningkatkan kepemilikan saham perusahaan oleh manajemen (kepemilikan manajerial), selain itu manajer dapat merasakan langsung manfaat dari keputusan yang diambil. Kepemilikan ini akan mensejajarkan kepentingan manajemen dengan pemegang saham. Widjaja dan Kasenda (2008:142) menyatakan bahwa disamping kepemilikan oleh pihak manajemen, kepemilikan oleh pihak institusional sebagai monitoring agent juga dapat menurunkan agency cost. Adanya kepemilikan oleh institusional seperti perusahaan asuransi, perusahaan investasi dan kepemilikan oleh institusi lain akan mendorong pengawasan yang lebih optimal terhadap kinerja manajemen perusahaan.

Jensen dan Meckling (1976) menyatakan bahwa guna mengurangi konflik kepentingan antara principal dan agen dapat dilakukan dengan 
meningkatkan kepemilikan manajerial dalam suatu perusahaan, yang berarti bahwa kepemilikan manajerial dalam suatu perusahaan target akan mendorong penyatuan kepentingan antara principal dan agen dalam mendorong informasi positif yang lebih banyak pada publikasi terakhir sebelum pengumuman akuisisi.

Penggabungan usaha pada umumnya dilakukan dalam bentuk merger, akuisisi, dan konsolidasi. Akuisisi merupakan cara pengembangan dan pertumbuhan perusahaan, akuisisi merupakan alternatif investasi modal pertumbuhan secara internal. Aktivitas akuisisi semakin meningkat seiring dengan intensnya perkembangan ekonomi yang makin mengglobal.

Demikian pula di Indonesia dengan adanya peraturan perundang-undangan yang mempermudah masuknya investor asing, merger dan akuisisi, maka pelaksanaan merger dan akuisisi meningkat (Saiful,2003).

Perubahan-perubahan yang terjadi setelah perusahaan melakukan merger dan akuisisi biasanya akan tampak pada kinerja perusahaan dan penampilan finansialnya. Pasca merger dan akuisisi kondisi dan posisi keuangan perusahaan mengalami perubahan dan hal ini tercermin dalam laporan keuangan perusahaan yang melakukan merger dan akuisisi. Untuk menilai bagaimana keberhasilan merger dan akuisisi yang dilakukan, dapat dilihat dari kinerja perusahaan setelah melakukan merger dan akuisisi terutama kinerja keuangan baik bagi perusahaan pengakuisisi maupun perusahaan diakuisisi. Dasar logika dari pengukuran berdasar akuntansi adalah bahwa jika skala bertambah besar ditambah dengan sinergi yang dihasilkan dari gabungan aktivitas-aktivitas yang simultan, maka laba perusahaan juga semakin meningkat sehingga kinerja perusahaan pasca merger dan akuisisi seharusnya semakin baik dibandingkan dengan sebelum merger dan akuisisi.

Dengan melihat latar belakang masalah tersebut, maka pertanyaan penelitian yang dilakukan adalah sebagai berikut:

1. Apakah terdapat perbedaan kepemilikan manajerial pada perusahaan pada saat sebelum dan sesudah merger?

2. Apakah terdapat perbedaan kinerja keuangan perusahaan pada saat sebelum dan sesudah merger?

adalah:

Tujuan dari penelitian yang dilakukan

1. Untuk menguji apakah terdapat perbedaan kepemilikan manajerial pada perusahaan pada saat sebelum dan sesudah merger?

2. Untuk menguji apakah terdapat perbedaan kinerja keuangan perusahaan pada saat sebelum dan sesudah merger?

\section{REVIEW LITERATUR DAN HIPOTESIS}

\section{Kepemilikan Manajerial}

Wewenang yang diberikan pemilik kepada manajer dalam mengelola perusahaan terkadang disalahgunakan oleh manajer yang bertindak sesuka hati untuk kepentingan sendiri (individu) dan tidak sesuai dengan keinginan principal yaitu meningkatkan kesejahteraan pemilik yang berujung pada munculnya konflik agency. Konflik yang dapat ditimbulkan dari perbedaan kepentingan antara manajemen dan pemilik yaitu pemegang saham yang sering memunculkan suatu pertentangan dapat dijelaskan dalam suatu teori keagenan (Lestari, 2010). Menurut Sartono (2010:10) terjadinya konflik keagenan dalam perusahaan dapat terjadi dimana manajernya memiliki saham kurang dari seratus persen. Mekanisme untuk mengatasi konflik keagenan antara lain meningkatkan kepemilikan insider (insider ownership) sehingga dapat mensejajarkan kepentingan pemilik dengan manajer (Indahningrum, 2009 yang dikutip dari penelitian Jensen dan Meckling, 1976).

Pemilik perusahaan publik mengalami kesulitan dalam mengendalikan perusahaan secara langsung dikarenakan: (1) ukuran 
perusahaan yang semakin besar sehingga sulit untuk mengelolanya sendiri, (2) memerlukan keahlian khusus yang semakin komplek dalam mengelola organisasi yang besar dimana umumnya pemilik memiliki keterbatasan dalam hal ini, (3) karena kepemilikan ditentukan oleh jumlah saham yang dimiliki yang berarti pemilik bisa lebih dari satu orang atau organisasi sehingga tidak memungkinkan apabila seluruh pemilik menjalankan operasi perusahaan. Berdasarkan permasalahan-permasalahan tersebut, maka pemilik (pemegang saham) sebagai prinsipal menyewa agen (manajer) untuk menjalankan perusahaan.

Agen (manajer) melakukan pengelolaan perusahaan dimana manajer bertanggung jawab terhadap pengambilan keputusan strategis dalam operasional sehari-hari perusahaan. Kinerja manajerini nantinyaakan dipertanggungjawabkan pada pemegang saham (pemilik). Pemisahan fungsi kepemilikan dan pengambilan keputusan dimana prinsipal menyewa agen untuk bekerja demi kepentingan prinsipal ini menimbulkan hubungan agensi (Jensen and Meckling,1976).

Pemegang saham membeli saham perusahaan dengan harapan memperoleh tingkat pengembalian atas investasi mereka yang setinggi-tingginya dengan tingkat resiko yang dapat ditolerir. Manajer yang dipilih dan dibayar oleh pemegang saham harus berusaha mengeluarkan kebijakan-kebijakan untuk meningkatkan kesejahteraan prinsipal. Peningkatan kesejahteraan ini identik dengan tujuan perusahaan yaitu meningkatkan nilai perusahaan melalui peningkatan kesejahteraan pemilik atau pemegang saham yang dapat dilakukan melalui kebijakan investasi dan keuangan yang tercermin dalam harga saham di pasar modal. Semakin tinggi harga saham berarti kesejahteraan pemilik semakin meningkat dan nilai perusahaan juga akan meningkat (Bringham and Ehrdhart ,2005).
Jensen (2001) mengungkapkan bahwa untuk mencapai tujuan perusahaan dan meningkatkan nilai perusahaan dalam jangka panjang manajer dituntut untuk membuat keputusan yang memperhitungkan kepentingan semua stakeholders, dimana seperti yang dinyatakan oleh Ismiyanti dan Hanafi (2004) para stakeholders ini masing-masing memiliki kepentingan sendiri. Menurut Zulhawati (2004) terkait dengan perbedaan kepentingan ini, manajemen atau manajer perusahaan cenderung lebih mengutamakan kepentingannya yang umumnya bertentangan dengan tujuan utama perusahaan. Pemegang saham tidak menyukai hal tersebut karena dapat menambah biaya (cost) perusahaan sehingga akan menurunkan keuntungan yang diterima (Wahidahwati,2001).

Para pemegang saham yang mempunyai kedudukan di manajemen perusahaan baik sebagai kreditur maupun sebagai dewan komisaris disebut sebagai kepemilikan manajerial (managerial ownership). Adanya kepemilikan saham oleh pihak manajemen akan menimbulkan suatu pengawasan terhadap kebijakan-kebijakan yang diambil oleh manajemen perusahaan. Kepemilikan manajerial juga dapat diartikan sebagai persentase saham yang dimiliki oleh manajer dan direktur perusahaan pada akhir tahun untuk masing-masing periode pengamatan. Masalah teknis tidak akan timbul jika kepemilikan dan pengelolaan perusahaan tidak dijalankan secara terpisah. Pemilik (pemegang saham) bertujuan untuk memaksimumkan kekayaannya dengan melihat nilai sekarang dari arus kas yang dihasilkan oleh investasi perusahaan sedangkan manajer bertujuan pada peningkatan pertumbuhan dan ukuran perusahaan. Tujuan manajer ini dilandasi oleh dua alasan, yaitu : 1). Pertumbuhan yang meningkat akan memberikan peluang bagi manajer bawah dan menengah untuk dipromosikan. Selain itu, manajer dapat membuktikan diri sebagai karyawan yang produktif sehingga dapat diperoleh penghargaan 
lebih dari wewenang untuk menentukan pengeluaran (biaya-biaya), 2). Ukuran perusahaan yang semakin besar memberikan keamanan pekerjaan atau mengurangi kemungkinan lay-off dan kompensasi yang semakin besar. Semakin besar proporsi kepemilikan manajemen pada perusahaan, maka manajemen cenderung berusaha lebih giat untuk kepentingan pemegang saham yang tidak lain adalah dirinya sendiri. Kepemilikan saham manajerial akan membantu penyatuan kepentingan antar manajer dengan pemegang saham. Kepemilikan manajerial akan mensejajarkan kepentingan manajemen dengan pemegang saham, sehingga manajer ikut merasakan secaralangsung manfaatdarikeputusan yang diambil dan ikut pula menanggung kerugian sebagai konsekuensi dari pengambilan keputusan yang salah. Argumen tersebut mengindikasikan mengenai pentingnya kepemilikan manajerial dalam struktur kepemilikan perusahaan.

Semakin bertambahnya saham yang dimiliki manajer melalui kepemilikan manajerial akan memotivasi kinerja manajemen karena mereka merasa memiliki andil dalam perusahaan baik itu dalam pengambilan keputusan dan bertanggungjawab terhadap keputusan yang diambil karena ikut sebagai pemegang saham perusahaan sehingga kinerja manajemen semakin baik dan berpengaruh pada peningkatan nilai perusahaan. Kepemilikan manajerial (insider ownership) diukur sesuai proporsi kepemilikan saham yang dimiliki oleh manajerial (Iturriaga, et al. 2001).

Kepemilikan manajerial adalah kepemilikan saham oleh manajemen perusahaan yang diukur dengan presentase jumlah saham yang dimiliki oleh manajemen Sujono dan Soebiantoro (2007) dalam Sabrina (2010). Struktur kepemilikan manajerial dapat dijelaskan melalui dua sudut pandang, yaitu pendekatan keagenan dan pendekatan ketidakseimbangan. Pendekatan keagenan menganggap struktur kepemilikan manajerial sebagai suatu instrument atau alat yang digunakan untuk mengurangi konflik keagenan diantara beberapa klaim terhadap sebuat perusahaan. Pendekatan ketidakseimbangan informasi memandang mekanisme struktur kepemilikan manajerial sebagai suatu cara untuk mengurangi ketidakseimbangan informasi antara insider dengan outsider melalui pengungkapan informasi didalam perusahaan.

Meningkatkan kepemilikan manajerial digunakan sebagai salah satu cara untuk mengatasi masalah yang ada di perusahaan. Dengan meningkatnya kepemilikan manajerial maka manajer akan termotivasi untuk meningkatkan kinerjanya sehingga dalam hal ini akan berdampak baik kepada perusahaan serta memenuhi keinginan dari para pemegang saham. Semakin besar kepemilikan manajerial dalam perusahaan maka manajemen akan lebih giat untuk meningkatkan kinerjanya karena manajemen mempunyai tanggung jawab untuk memenuhi keinginan dari pemegang saham yang tidak lain adalah dirinya sendiri. Manajemen akan lebih berhati-hati dalam mengambil suatu keputusan, karena manajemen akan ikut merasakan manfaat secara langsung dari keputusan yang diambil. Selain itu manajemen juga ikut menanggung kerugian apabila keputusan yang diambil oleh mereka salah.

\section{Kinerja Keuangan}

Laporan keuangan pada dasarnya adalah hasil dari proses akuntansi yang dapat digunakan sebagai alat untuk berkomunikasi antara data keuangan atau aktivitas suatu perusahaan dengan pihak-pihak yang berkepentingan dengan data atau aktivitas perusahaan tersebut (Munawir 1995: 2).

Menurut Hanafi (2003: 69), laporan keuangan merupakan informasi yang dapai dipakai untuk pengambilan keputusan, mulai dari investor atau calon investor sampai dengan manajemen perusahaan itu sendiri. Laporan keuangan akan memberikan informasi mengenai 
profitabilitas, risiko, timing aliran kas, yang kesemuanya akan mempengaruhi harapan pihakpihak yang berkepentingan.

Menurut Munawir (1995: 5), laporan keuangan itu terdiri dari neraca dan perhitungan laba-rugi serta laporan perubahan modal. Dimana neraca menunjukan jumlah aktiva, hutang dan modal dari suatu perusahaan pada tanggal tertentu, sedangkan pehitungan laporan laba-rugi memperlihatkan hasil-hasil yang telah dicapai oleh perusahaan serta biaya yang terjadi selama tertentu, dan laporan perubahan modal menunjukan sumber dan penggunaan atau alasanalasan yang menyebabkan perubahan modal perusahaan.

Berdasarkan kedua pendapat di atas dapat disimpulkan bahwa laporan keuangan merupakan salah satu informasi yang penting bagi perusahaan dengan pihak-pihak yang berkepentingan dengan data-data yang terdiri dari neraca, dan perhitungan laba-rugi serta keterangan yang dimuat dalam lampiran-lampirannya.

\section{Jenis-jenis Laporan Keuangan}

Menurut Warsono (2001: 25) ada 2 macam bentuk laporan keuangan utama yang dihasilkan oleh suatu perusahaan yaitu Neraca dan Laporan laba rugi.

a. Neraca

Menurut Warsono (2001: 25), neraca adalah laporan keuangan yang menggambarkan posisi keuangan suatu organisasi pada suatu periode tertentu. Neraca perusahaan ini disusun berdasarkan persamaan dasar akuntansi, yaitu bahwa kekayaan atau aktiva (asets) sama dengan kewajiban (liabilities) ditambah modal saham (stock equities).

b. Laporan laba-rugi

Menurut Warsono (2001: 26), laporan laba-rugi adalah laporan keuangan yang mengambarkan hasil-hasil usaha yang dicapai selama periode tertentu. Laba rugi bersih adalah selisih antara pendapatan total dengan biaya atau pengeluaran total. Pendapatan mengukur aliran masuk asset bersih (setelah dikurangi utang) dari penjualan barang atau jasa. Sedangkan menurut pendapat Halim (1994: 20), laporan keuangan dapat dibagi menjadi 2 jenis antara lain:

a. Neraca

Neraca menunjukan aktiva, utang, dan modal sendiri suatu perusahaan pada hari terakhir periode akuntansi.

b. Laporan laba-rugi

Laporan laba-rugi adalah suatu laporan atas kegiatan-kegiatan perusahaan selama waktu periode akuntansi tertentu. Laporan laba-rugi menunjukan penghasilan dan biaya operasi, bunga, pajak, dan laba bersih yang diperoleh suatu perusahaan. Laporan laba-rugi merupakan suatu produk akauntansi yang dirancang untuk menunjukan kepada pemegang saham dan kreditur, apakah perusahaan dapat menghasilkan keuntungan.

\section{Tujuan Laporan Keuangan}

Hanafi (2003: 30) menyatakan bahwa tujuan laporan keuangan yaitu pertama, memberikan informasi yang bermanfaat bagi investor, kreditur, dan pemakai lainnya sekarang atau masa yang akan datang untuk membuat keputusan investasi. Kedua, memberikan informasi yang bermanfaat untuk pemakai eksternal untuk memperkirakan jumlah waktu, dan ketidakpastian dari penerimaan kas dari bunga dan dari penjualan atau hutang pinjaman. Ketiga, Memberi informasi untuk menolong infestor, kreditur, dan pemakai lainnya untuk memperkirakan jumlah waktu, dan ketidakpastian aliran kas masuk bersih ke perusahaan.

Berdasarkan pendapat tersebut diatas dapat disimpulkan bahwa tujuan laporan keuangan yaitu dapat memberikan informasi mengenai sumber daya ekonomi kewajiban, dan modal sendiri dari suatu perusahaan dan sebagai 
alat untuk berkomunikasi antara data keuangan suatu perusahaan dengan pihak-pihak yang berkepentingan.

Perusahaan sebagai salah satu bentuk organisasi pada umumnya memiliki tujuan tertentu yang ingin dicapai dalam usaha untuk memenuhi kepentingan para anggotanya. Keberhasilan dalam mencapai tujuan perusahaan merupakan prestasi manajemen. Penilaian prestasi atau kinerja suatu perusahaan diukur karena dapat dipakai sebagai dasar pengambilan keputusan baik pihak internal maupun eksternal. Kinerja perusahaan merupakan suatu gambaran tentang kondisi keuangan suatu perusahaan yang dianalisis dengan alat-alat analisis keuangan, sehingga dapat diketahui mengenai baik buruknya keadaan keuangan suatu perusahaan yang mencerminkan prestasi kerja dalam periode tertentu. Hal ini sangat penting agar sumber daya digunakan secara optimal dalam menghadapi perubahan lingkungan. Penilaian kinerja keuangan merupakan salah satu cara yang dapat dilakukan oleh pihak manajemen agar dapat memenuhi kewajibannya terhadap para penyandang dana dan juga untuk mencapai tujuan yang telah ditetapkan oleh perusahaan.

Kinerja keuangan suatu perusahaan dapat diartikan sebagai prospek atau masa depan, pertumbuhan, dan potensi perkembangan yang baik bagi perusahaan. Informasi kinerja keuangan diperlukan untuk menilai perubahan potensial sumber daya ekonomi, yang mungkin dikendalikan di masa depan dan untuk memprediksi kapasitas produksi dari sumber daya yang ada (Barlian, 2003). Pimpinan perusahaan atau manajemen sangat berkepentingan terhadap laporan keuangan yang telah di analisis, karena hasil tersebut dapat dijadikan sebagai alat dalam pengambilan keputusan lebih lanjut untuk masa yang akan datang. Dengan menggunakan análisis rasio, berdasarkan data dari laporan keuangan, akan dapat diketahui hasil-hasil financial yang telah di capai di waktu-waktu yang lalu, dapat diketahui kelemahan-kelemahan yang dimiliki perusahaan, serta hasil-hasil yang di anggap cukup baik.

Baik buruknya kondisi suatu perusahaan dapat dinilai dari kinerja keuangan dengan menganalisa rasio keuangan salah satunya rasio profitabilitas yang dapat diukur dari return on asset. Profitabilitas menunjukkan kemampuan perusahaan memperoleh laba atau ukuran efektivitas pengelolaan manajemen perusahaan (Wiagustini, 2010:76). Perusahaan yang mampu bertumbuh yang ditunjukkan dengan semakin tingginya profitabilitas yang dihasilkan perusahaan dikaitkan bagaimana suatu perusahaan bisa mendayagunakan sumber daya atau asset yang ada dalam perusahaan untuk menghasilkan laba, yang nantinya mampu menciptakan nilai perusahaan yang tinggi dan memaksimumkan kekayaan pemegang sahamnya dan akan memeroleh tanggapan yang positif dari pihak luar.

Produktifitas yang dilakukan perusahaan sebagai kemampuan perusahaan untuk memberikan nilai terhadap perusahaan adalah kinerja perusahaan. Penilaian kinerja merupakan sangat penting bagi perusahaan yang telah go public. Perusahaan go public adalah perusahaan yang dimiliki oleh masyarakat sehingga dituntut untuk meningkatkan kinerjanya. Penilaian kinerja ini sangat penting sebagai proses merger perusahaan sehingga diketahui nilai perusahaan. Penilaian kinerja juga sangat dibutuhkan oleh perusahaan yang mengalami kesulitan, penilaian kinerja juga sangat berguna untuk restrukturisasi pengimplementasian program pemulihan usaha, bagi perusahaan yang go public penilaian kinerja sangat penting jika perusahaan akan menjual perusahaannya dibursa harus melakukan penilaian untuk menentukan nilai wajar saham yang akan ditawarkan kepada masyarakat.

Gaughan (1996), mengidentifikasikan rasio-rasio keuangan yang secara signifikan memberikan perbedaan kinerja keuangan 
perusahaan setelah merger dan akuisisi, yaitu :

1. Rasio Profitabilitas (profitability ratio) Adalah rasio-rasio yang menunjukkan keberhasilan perusahaan dalam menghasilkan keuntungan. Meliputi antara lain:

- Net Profit Margin (NPM) Yaitu rasio yang digunakan untuk mengukur tingkat kembalian keuntungan bersih terhadap penjualan bersihnya.

- Return on Asset (ROA)

Yaitu rasio yang digunakan untuk mengukur efektivitas perusahaan dalam menghasilkan keuntungan dengan memanfaatkan aktiva yang dimiliki.

2. Rasio Aktivitas (activity ratio)

Adalah rasio-rasio yang dimaksudkan untuk mengukur kemampuan atau efisiensi perusahaan dalam memanfaatkan aktiva yang dimilikinya atau perputaran (turn over) dari aktiva-aktiva tersebut. Meliputi antara lain:

- Total Asset Turnover (TATO)

Yaitu rasio yang menunjukkan seberapa efektifnya perusahaan menggunakan total asetnya.

\section{Merger}

Ketentuan dan definisi mengenai AMKP ini telah diatur dalam Pasal 122 Undang-undang Nomor 40 Tahun 2007 tentang Perseroan Terbatas . Dengan keberadaan Perseroan Terbatas tersebut dalam dunia usaha sangatlah penting dalam kegiatan pembangunan ekonomi dunia dalam arus globalisasi dan liberalisasi perekonomian. Oleh karena itu, Pemerintah melakukan suatu suatu bentuk dukungan dan memfasilitasi akan realisasi pertumbuhan perekonomian Indonesia dengan membentuk suatu peraturan-peraturan yang akan menjadi wadah dan pedoman dalam melakukan tindakan korporasi Merger ini .

Merger adalah proses difusi atau penggabungan dua perseroan dengan salah satu diantaranya tetap berdiri dengan nama perseroannya sementara yang lain lenyap dengan segala nama dan kekayaannya dimasukan dalam perseroan yang tetap berdiri tersebut . Merger dalam bahasa Inggris berarti "Penggabungan", sedangkan dalam bahasa Latin berarti "bergabung bersama, menyatu, atau berkombinasi yang menyebabkan hilangnya identitas karena terserap sesuatu".

Sehingga berdasarkan pernyataan tersebut diatas, Merger berarti adalah suatu tindakan ekspansi perusahaan atau restrukturisasi perusahaan melalui cara yaitu menggabungkan dua perusahaan atau lebih dimana hanya ada satu perusahaan dan salah satu perusahaan yang menggabungkan diri menjadi bubar karena hukum tanpa likuidasi terlebih dahulu.

Merger adalah salah satu bentuk absorsi/ penyerapan yang dilakukan oleh satu perusahaan terhadap perusahaan yang lain. Jika terjadi merger antara perusahaan $\mathrm{A}$ dan perusahaan $\mathrm{B}$, maka pada akhirnya hanya akan ada satu perusahaan saja, yaitu perusahaan A atau B. Pada sebagian besar kasus merger, perusahaan yang memilki ukuran yang lebih besar yang dipertahankan hidup dan tetap mempertahankan nama dan status hukumnya, sedangkan perusahaan yang berukuran lebih kecil atau perusahaan yang dimerger akan menghentikan aktivitas atau dibubarkan sebagai badan hukum (Lani Dharmasetya dan Vonny Sulaimin, 2009: 10).

Bentuk lain dari penyatuan perusahaan adalah pengambilalihan perusahaan, yang sering disebut dengan akuisisi. Pada akuisisi, masing-masing perusahaan, baik perusahaan yang mengambil alih maupun perusahaan yang diambil alih tetap mempertahankan aktivitasnya, identitasnya, dan kedudukannya sebagai perusahaan yang mandiri. Praktik akuisisi melahirkan hubungan induk perusahaan (perusahaan yang mengambil alih) dan anak perusahaan (perusahaan yang diambil alih) (Lani Dharmasetya dan Vonny Sulaimin, 2009:11). 


\section{Alasan-alasan Melakukan Merger dan Akuisisi}

Ada beberapa alasan perusahaan melakukan penggabungan baik melalui merger maupun akuisisi, yaitu :

\section{a. Pertumbuhan atau diversifikasi}

Perusahaan yang menginginkan pertumbuhan yang cepat, baik ukuran, pasar saham, maupun diversifikasi usaha dapat melakukan merger maupun akuisisi. Perusahaan tidak memiliki resiko adanya produk baru. Selain itu, jika melakukan ekspansi dengan merger dan akuisisi, maka perusahaan dapat mengurangi perusahaan pesaing atau mengurangi persaingan.

\section{b. Sinergi}

Sinergi dapat tercapai ketika merger menghasilkan tingkat skala ekonomi (economies of scale). Tingkat skala ekonomi terjadi karena perpaduan biaya overhead meningkatkan pendapatan yang lebih besar daripada jumlah pendapatan perusahaan ketika tidak merger. Sinergi tampak jelas ketika perusahaan yang melakukan merger berada dalam bisnis yang sama karena fungsi dan tenaga kerja yang berlebihan dapat dihilangkan.

\section{c. Meningkatkan dana}

Banyak perusahaan tidak dapat memperoleh dana untuk melakukan ekspansi internal, tetapi dapat memperoleh dana untuk melakukan ekspansi eksternal. Perusahaan tersebut menggabungkan diri dengan perusahaan yang memiliki likuiditas tinggi sehingga menyebabkan peningkatan daya pinjam perusahaan dan penurunan kewajiban keuangan. Hal ini memungkinkan meningkatnya dana dengan biaya rendah.

\section{d. Menambah ketrampilan manajemen atau teknologi}

Beberapa perusahaan tidak dapat berkembang dengan baik karena tidak adanya efisiensi pada manajemennya atau kurangnya teknologi. Perusahaan yang tidak dapat mengefisiensikan manajemennya dan tidak dapat membayar untuk mengembangkan teknologinya, dapat menggabungkan diri dengan perusahaan yang memiliki manajemen atau teknologi yang ahli.

\section{e. Pertimbangan pajak}

Perusahaan dapat membawa kerugian pajak sampai lebih 20 tahun ke depan atau sampai kerugian pajak dapat tertutupi. Perusahaan yang memiliki kerugian pajak dapat melakukan akuisisi dengan perusahaan yang menghasilkan laba untuk memanfaatkan kerugian pajak. Pada kasus ini perusahaan yang mengakuisisi akan menaikkan kombinasi pendapatan setelah pajak dengan mengurangkan pendapatan sebelum pajak dari perusahaan yang diakuisisi. Bagaimanapun merger tidak hanya dikarenakan keuntungan dari pajak, tetapi berdasarkan dari tujuan memaksimisasi kesejahteraan pemilik.

\section{f. Meningkatkan likuiditas pemilik}

Merger antar perusahaan memungkinkan perusahaan memiliki likuiditas yang lebih besar. Jika perusahaan lebih besar, maka pasar saham akan lebih luas dan saham lebih mudah diperoleh sehingga lebih likuid dibandingkan dengan perusahaan yang lebih kecil.

\section{g. Melindungi diri dari pengambilalihan}

Hal ini terjadi ketika sebuah perusahaan menjadi incaran pengambilalihan yang tidak bersahabat. Target firm mengakuisisi perusahaan lain, dan membiayai pengambilalihannya dengan hutang, karena beban hutang ini, kewajiban perusahaan menjadi terlalu tinggi untuk ditanggung oleh bidding firm yang berminat (Gitman, 2003, p.714716). 


\begin{abstract}
METODE PENELITIAN

\section{Populasi dan Sampel}

Objek penelitian ini adalah perusahaan yang melakukan merger dan akuisisi yang terdaftar di Bursa Efek Indonesia. Dalam penelitian ini pengambilan sampel yang dilakukan secara non probability sampling, yaitu dengan pendekatan purposive sampling dengan kriteria sebagai berikut. (1) Perusahaan yang terdaftar di Bursa Efek Indonesia dan melakukan merger antara tahun 2007 sampai dengan tahun 2011. (2) Perusahaan memiliki tanggal merger yang jelas. (3) Menerbitkan laporan keuangan auditan secara lengkap selama satu tahun sebelum merger serta setelah merger dengan periode berakhir per 31 Desember.
\end{abstract}

\section{Teknik Pengambilan Sampel}

Teknik sampling adalah merupakan teknik pengambilan sampel. Untuk menentukan sampel yang akan digunakan dalam penelitian, terdapat berbagai teknik sampling yang digunakan (Sugiyono, 2008: 217). Teknik pengambilan sampel dalam penelitian ini dilakukan secara non probability sampling, yaitu dengan pendekatan purposive sampling.

\section{Teknik Pengumpulan Data}

Metode pengumpulan data yang digunakan dalam penelitian ini adalah dengan metode studi pustaka yang dilakukan dalam rangka mengumpulkan teori-teori atau literaturliteratur yang dapat dipergunakan sebagai landasan yang berhubungan dengan masalah yang sedang teliti. Berkaitan dengan data-data yang digunakan dalam penelitian ini, data-data yang dibutuhkan terdiri dari data sekunder. Data mengenai harga saham diperoleh dari Indonesian Capital Market Directory (ICMD), idx statistic, dan Bursa Efek Indonesia (BEI) di pojok BEI.

\section{Definisi Operasional Variabel Penelitian}

\section{Kepemilikan Manajerial}

Kepemilikan manajerial (managerial ownership) adalah tingkat atau jumlah persentase kepemilikan saham pihak manajemen yang secara aktif ikut dalam pengambilan keputusan, misalnya direktur dan komisaris. Dalam penelitian ini kepemilikan manajerial dihitung menggunakan rumus:

$$
\mathrm{INSD}=\frac{\text { Jumlah saham manajerial }}{\text { Jumlah saham beredar }} \times 100 \%
$$

\section{Kinerja Keuangan}

Kinerja keuangan didefinisikan sebagai prestasi manajemen keuangan untuk mencapai tujuan perusahaan yaitu menghasilkan keuntungan dan meningkatkan nilai perusahaan. Kinerja keuangan dalam penelitian ini di ukur dengan menggunakan rasio aktivitas dan profitabilitas.

1. Rasio Aktivitas menunjukkan kemampuan dana yang tertanam dalam keseluruhan aktiva berputar dalam suatu periode tertentu atau kemampuan modal yang di investasikan untuk menghasilkan revenue. Pengukuran rasio aktivitas disini menggunakan total asset turnover.

Total Asset Turnover $($ TATO $)=$ Penjualan $/$ Total aktiva

2. Rasio Profitabilitas mengukur seberapa besar kemampuan perusahaan memperoleh laba baik dalam hubungannya dengan penjualan, aset maupun laba bagi modal sendiri. Pengukuran rasio profitabilitas ini menggunakan net profit margin dan return on asset.

Net Profit Margin $(N P M)=$ EAT $/$ Penjualan neto

Return on Asset $=E A T /$ Total aktiva

\section{Uji Hipotesis dan Analisis Data}

Analisis rasio keuangan digunakan untuk menganalisis keputusan merger dan akuisisi terhadap kondisi keuangan rasio-rasio 
tersebut dibandingkan dengan rasio sebelum merger. Langkah pertama yang dilakukan adalah menghitung masing-masing rasio keuangan yang sudah ditetapkan sebagai variabel penelitian. Hasil perhitungan rasio-rasio ini selanjutnya digunakan sebagai data dalam pengujian statistik. paired sample t-test digunakan untuk menganalisis Apakah terdapat perbedaan kepemilikan manajerial pada perusahaan pada saat sebelum dan sesudah merger.

Uji paired sample t-test digunakan untuk menguji hipotesis 1 dan hipotesis 2, yakni untuk membuktikan Apakah terdapat perbedaan kepemilikan manajerial pada perusahaan pada saat sebelum dan sesudah merger. Apakah terdapat perbedaan kinerja keuangan jika dilihat dari segi rasio aktivitas yang di ukur dengan total asset turnover dan rasio profitabilitas yang di ukur dengan net profit margin dan return on asset pada periode sebelum dan setelah pelaksanaan merger.

\section{HASIL PENELITIAN DAN PEMBAHASAN}

\section{Gambaran Umum Sampel}

Berdasarkan data pada Tabel 1 dan berdasarkan kriteria sampel yang diajukan dalam penelitian ini, maka peneliti menetapkan perusahaan yang memenuhi syarat untuk dijadikan sampel dalam penelitian ini adalah sebagai berikut, Trias Sentosa Tbk, Barito Pacific Tbk, Astra International Tbk, United Tractors Tbk, Bentoel International Investama Tbk, Metrodata Electronics Tbk, Sumalindo Lestari Jaya Tbk, Bank Niaga Tbk, Indofood Sukses Makmur Tbk, Bank OCBC NISP Tbk, Unilever Holding BV. Sedangkan perusahaan yang lain tergolong perusahaan yang melakukan merger tidak memenuhi persyaratan sebagai sampel.
Tabel 1

Daftar Perusahaan Merger 2007 - 2011

\begin{tabular}{|c|c|c|c|c|c|}
\hline \multirow{2}{*}{ No } & \multicolumn{3}{|c|}{ Waktu } & \multirow{2}{*}{ Keterangan } & \multirow{2}{*}{ Jenis } \\
\hline & Tahun & Bulan & Tanggal & & \\
\hline 1 & 2007 & Juli & 3 & $\begin{array}{l}\text { Trias Sentosa Tbk } \\
\text { dengan AKKU,AKPI }\end{array}$ & Merger \\
\hline 2 & 2007 & Juli & 9 & $\begin{array}{l}\text { Barito Pacific Tbk } \\
\text { dengan DSUC, SULI }\end{array}$ & Merger \\
\hline 3 & 2007 & Desember & 6 & $\begin{array}{l}\text { Astra International Tbk } \\
\text { dengan BRAM, GJTI }\end{array}$ & Merger \\
\hline 4 & 2008 & Januari & 14 & $\begin{array}{l}\text { United Tractors Tbk } \\
\text { dengan HEXA, IMAS }\end{array}$ & Merger \\
\hline 5 & 2008 & Januari & 31 & $\begin{array}{l}\text { Bentoel International } \\
\text { Investama Tbk dengan } \\
\text { BATI, GGRM }\end{array}$ & Merger \\
\hline 6 & 2008 & Mei & 22 & $\begin{array}{l}\text { Metrodata Electronics } \\
\text { Tbk dengan ASGR, } \\
\text { MLPI }\end{array}$ & Merger \\
\hline 7 & 2008 & Juni & 6 & $\begin{array}{l}\text { Sumalindo Lestari Jaya } \\
\text { Tbk dengan BRPT, } \\
\text { DSUC }\end{array}$ & Merger \\
\hline 8 & 2008 & Juli & 1 & $\begin{array}{l}\text { Bank Niaga Tbk } \\
\text { dengan Bank Lippo }\end{array}$ & Merger \\
\hline 9 & 2008 & Agustus & 26 & $\begin{array}{l}\text { Indofood Sukses } \\
\text { Makmur Tbk dengan } \\
\text { MYOR, SKBM }\end{array}$ & Merger \\
\hline 10 & 2009 & Desember & 23 & $\begin{array}{l}\text { Bentoel International } \\
\text { Investama Tbk dengan } \\
\text { BAT Indonesia Tbk }\end{array}$ & Merger \\
\hline 11 & 2010 & September & 24 & $\begin{array}{l}\text { Bank OCBC NISP Tbk } \\
\text { dengan Bank OCBC } \\
\text { Indonesia }\end{array}$ & Merger \\
\hline 12 & 2010 & Desember & 27 & $\begin{array}{l}\text { PT Astra international } \\
\text { Tbk. dengan PT } \\
\text { General Electric } \\
\text { Services }\end{array}$ & Merger \\
\hline 13 & 2011 & Januari & 6 & $\begin{array}{l}\text { Unilever Holding BV } \\
\text { dengan Sara Lee Body } \\
\text { Care, Tbk }\end{array}$ & Merger \\
\hline
\end{tabular}

Sumber : Pojok Bursa Efek Indonesia

\section{Kondisi umum data yang akan dianalisis}

Data yang diperlukan dalam penelitian ini adalah data laporan keuangan tahunan perusahaan pengakuisisi dan data keuangan satu tahun pasca perusahaan melakukan merger. Laporan keuangan yang diperlukan dalam penelitian ini adalah neraca untuk melihat nilai aktiva dan kewajiban perusahaan, laporan laba rugi untuk melihat nilai penjualan bersih perusahaan dan laporan arus kas perusahaan untuk melihat nilai arus kas bersih perusahaan yang akan dijadikan dasar untuk menilai manajemen laba perusahaan. Laporan keuangan dalam penelitian ini dapat dilihat dalam lampiran 
Langkah - langkah Analisis Data

Berdasarkan kondisi umum data yang akan dianalisis maka, langkah-langkah dalam analisis data ini adalah mencari nilai kepemilikan manajerial dan selanjutnya peneliti mencari nilai rasio keuangan yang sudah ditetapkan sebagai variabel yaitu rasio aktivitas dan rasio profitabilitas sebelum merger dan setelah merger, tujuannya untuk memperoleh hasil kinerja keuangan perusahaan apakah mengalami peningkatan, penurunan dalam kondisi keuangan yang sehat atau tidak. Dari hasil tersebut maka akan diperoleh suatu kesimpulan mengenai kinerja keuangan perusahaan sebelum dan sesudah melakukan merger.

Table 2

Ringkasan Hasil Analisis

\begin{tabular}{|l|c|l|}
\hline \multicolumn{1}{|c|}{ Variabel } & Sig. & Ket. \\
\hline $\begin{array}{l}\text { Kepemilikan } \\
\text { Manajerial }\end{array}$ & 0,286 & Tidak Signifikan \\
\hline total asset turnover & 0,085 & Tidak Signifikan \\
\hline net profit margin & 0,362 & Tidak Signifikan \\
\hline return on assets & 0,531 & Tidak Signifikan \\
\hline
\end{tabular}

\section{Pengujian hipótesis kesatu}

Hipotesis kedua menyatakan bahwa terdapat perbedaan kepemilikan manajerial sebelum dan sesudah merger. Pengujian hipotesis kedua adalah untuk membuktikan adanya perbedaan kepemilikan manajerial sebelum dan sesudah merger. Pengujian dilakukan dengan metode paired samples t-test atau uji $\mathrm{T}$ sampel berpasangan yang merupakan uji parametrik yang digunakan untuk menguji hipotesis sama atau tidak berbeda (Ho) diantara dua variabel. Data berasal dari dua pengukuran atau dua periode pengamatan yang berbeda yang diambil subjek yang dipasangkan.

Berdasarkan hasil pengujian tersebut, dapat diketahui bahwa nilai signifikansi sebesar 0,286 (two tailed) pada tingkat kepercayaan 95\%. Karena probabilitas signifikansi $(0,286)$ lebih besar dari 0,05 maka dapat disimpulkan bahwa tidak terdapat perbedaan antara kepemilikan manajerial sebelum dan sesudah merger.
Berdasarkan hasil tersebut dapat disimpulkan bahwa hipotesis dua yang menyatakan bahwa Terdapat perbedaan kepemilikan manajerial pada perusahaan pada saat sebelum dan sesudah merge tidak terbukti. Berdasarkan hasil ini maka hipotesis nol (H0) yang menyatakan bahwa tidak terdapat perbedaan kepemilikan manajerial pada perusahaan pada saat sebelum dan sesudah merger dinyatakan diterima.

Hasil ini dapat dimungkinkan untuk terjadi dikarenakan keterbatasan periode pengamatan yang hanya satu tahun (satu tahun sebelum dan satu tahun setelah merger). Padahal metode pengamatan yang semakin panjang sebelum dan setelah merger dimungkinkan dapat menganalisis terjadinya optimalisasi kepemilikan manajerial sebelum dan setelah merger.

\section{Pengujian hipótesis kedua}

Hipotesis kedua menyatakan bahwa terdapat perbedaan kinerja keuangan yang di ukur dengan total asset turnover (TATO), net profit margin(NPM), dan returnon asset (ROA) sebelum dan sesudah merger dan akuisisi. Pengujian hipotesis kedua adalah untuk membuktikan adanya perbedaan kinerja keuangan sebelum dan sesudah merger dan akusisi. Pengujian dilakukan dengan metode paired samples t-test atau uji T sampel berpasangan yang merupakan uji parametrik yang digunakan untuk menguji hipotesis sama atau tidak berbeda (Ho) diantara dua variabel. Data berasal dari dua pengukuran atau dua periode pengamatan yang berbeda yang diambil subjek yang dipasangkan.

Berdasarkan hasil pengujian tersebut, dapat diketahui bahwa total asset turnover (TATO) dengan probabilitas signifikansi sebesar 0,085 (two tailed) pada tingkat kepercayaan $95 \%$. Karena probabilitas signifikansi $(0,085)$ lebih besar dari 0,05 maka dapat disimpulkan bahwa tidak terdapat perbedaan antara TATO sebelum dan sesudah merger pada perusahaan-perusahaan yang diestimasi. 
Adapun indikator net profit margin (NPM) dengan probabilitas signifikansi sebesar 0,362 (two tailed) pada tingkat kepercayaan $95 \%$. Karena probabilitas signifikansi $(0,362)$ lebih besar dari 0,05 maka dapat disimpulkan bahwa tidak terdapat perbedaan antara NPM sebelum dan sesudah merger pada perusahaan-perusahaan yang diestimasi.

Adapun indikator return on assets (ROA) dengan probabilitas signifikansi sebesar 0,531 (two tailed) pada tingkat kepercayaan $95 \%$. Karena probabilitas signifikansi $(0,531)$ lebih besar dari 0,05 maka dapat disimpulkan bahwa tidak terdapat perbedaan antara ROA sebelum dan sesudah merger pada perusahaan-perusahaan yang diestimasi.

Hasil ini dapat dimungkinkan untuk terjadi dikarenakan keterbatasan periode pengamatan yang hanya satu tahun (satu tahun sebelum dan satu tahun setelah merger). Padahal metode pengamatan yang semakin panjang sebelum dan setelah merger dimungkinkan dapat menganalisis optimalisasi kinerja perusahaan sebelum dan setelah merger.

\section{KESIMPULAN DAN SARAN}

\section{Kesimpulan}

Berdasarkanhasilanalisis dan pembahasan

yang telah disampaikan sebelumnya, simpulan yang dapat diambil dalam penelitian ini, adalah:

1. Penelitian ini membuktikan bahwa tidak terdapat tidak terdapat perbedaan antara kepemilikan manajerial sebelum dan sesudah merger.

2. Penelitian ini membuktikan bahwa kinerja keuangan yang diproksikan dengan total asset turnover (TATO), net provit margin (NPM) dan return on asset (ROA) tidak terdapat perbedaan kinerja keuangan perusahaan pada saat sebelum dan sesudah merger.

\section{Keterbatasan}

Penelitian ini memiliki keterbatasan. Beberapa hal yang menjadi keterbatasan dalam penelitian ini, adalah:

1. Penelitian ini hanya menggunakan sampel dalam jumlah yang terbatas, masih jarangnya

2. perusahaan yang melakukan aktivitas merger dan akuisisi pada pasar modal Indonesia menyebabkan sulitnya diperoleh jumlah sampel yang representative.

3. Penelitian ini tidak mampu membuktikan adanya perbedaan kepemilikan manajerial dan perbedaan kinerja perusahaan periode sebelum dan sesudah merger.

\section{Saran}

Setelah melakukan analisis pada penelitian ini ada beberapa saran yang bisa dijadikan masukan untuk mengkaji ulang, yaitu:

1. Peneliti selanjutnya perlu menambah variabel penelitian seperti rasio-rasio keuangan yang lain dan lebih memperpanjang tahun pengamatan dari 2 tahun menjadi 4 sampai 5 tahun.

2. Sebaiknya perusahaan jangan ragu-ragu melakukan merger jika ingin mengembangkan usahanya.

\section{DAFTAR PUSTAKA}

Andriyani, Ni Ketut. 2008. "Pengaruh Investment Opportunity Set (IOS), Mekanisme Corporate Governance, Ukuran Perusahaan, dan Leverage pada Kualitas Laba (Studi pada Perusahaan Manufaktur yang Terdaftar di Bursa Efek Indonesia Periode 2003-2007)". Skripsi, Sarjana Jurusan Akuntansi Fakultas Ekonomi, Universitas Udayana, Denpasar

Dewi, Made Sri Utami. 2008. "Analisis Kinerja Keuangan Sebelum dan Sesudah Akuisisi pada Perusahaan Go Public di PT.BEI". Skripsi, Sarjana Jurusan Akuntansi, Fakultas Ekonomi, Universitas Udayana, Denpasar 
Dharmasetya MM.,BKP, Lani dan Vonny Sulaimin, Msi.,CPA, 2009,Merger dan Akuisisi tinjauan dari sudut Akuntansi dan Perpajakan, Jakarta, PT Elex Media Komputindo KOMPAS GRAMEDIA

Hadiningsih, Murni. 2007. "Analisis Dampak Jangka Panjang Merger dan Akuisisi terhadap Kinerja Keuangan Perusahaan Pengakuisisi dan Perusahaan Diakuisisi di Bursa Efek Jakarta (BEJ)". Skripsi, Sarjana Jurusan Manajemen Keuangan, Fakultas Ekonomi, Universitas Islam Indonesia, Yogyakarta

Halim, Abdul dan Sarwoko. 1995. Manajemen

Keuangan (Dasar-dasar Pembelanjaan Perusahaan). YKPN, Yogyakarta.

Hitt, A Michael. 2002. Merger dan Akuisisi: Paduan Meraih Laba Bagi Para Pemegang Saham. Edisi 1, PT Raja Grafindo Persada, Jakarta

Indriyani Sijabat, Sarah. 2009. "Analisis Kinerja Keuangan Sebelum dan Sesudah Merger dan Akuisisi Pada Perusahaan yang Terdaftar di Bursa Efek Indonesia". Jurnal Akuntansi, Fakultas Ekonomi, Universitas Sumatera Utara
Isnani, Nurul dan Sri Iswati. 2001. "Pengaruh Merger Terhadap Kinerja Keuangan:Analisis Economic Value Added (EVA)". Majalah Ekonomi, FEUNDIP, Tahun XI No.3

Munawir. 1995. Analisis Laporan Keuangan. Edisi Empat. Liberty, Yogyakarta

Payamta, dan Sektiawan, 2004. "Analisis Pengaruh Merger dan Akuisisi Kinerja

Perusahaan Publik di Indonesia". Jurnal Riset Akuntansi Indonesia, Vol. 7 No 3

Payamta, 2000. "Analisis Pengaruh Keputusan Merger dan Akuisisi terhadap Perubahan Kinerja Perusahaan Publik di Indonesia". Disampaikan pada Simposium Nasional Akuntansi Indonesia IV

Saiful, 2003. "Abnormal Return Perusahaan Target dan Industri Sejenis Seputar Sektor Pengumuman Merger dan Akuisisi". Jurnal Riset Ekonomi dan Manajemen, Vol.3 No.1

Warsono. 2003.Manajemen Keuangan Perusahaan. Edisi tiga. Jilid satu. Bayu Media Publishing. Malang. 